\title{
DOES ESG PERFORMANCE AFFECT THE FINANCIAL PERFORMANCE OF ENVIRONMENTALLY SENSITIVE INDUSTRIES? A COMPARISON BETWEEN EMERGING AND DEVELOPED MARKETS
}

\author{
DOI: 10.17261/Pressacademia.2021.1509 \\ PAP- V.14-2021(35)-p.135-136
}

\section{Nasruzzaman Naeem ${ }^{1}$, Serkan Cankaya ${ }^{2}$}

${ }^{1}$ Istanbul Commerce University, Graduate School of Finance, Istanbul, Turkey. anm naeem@yahoo.com, ORCID: 0000-0001-5103-7645

${ }^{2}$ Istanbul Commerce University, Department of Finance and Banking, Istanbul, Turkey. scankaya@ticaret.edu.tr, ORCID: 0000-0003-3010-0697

\begin{abstract}
To cite this document
Naeem, N., Cankaya, S., (2021). Does ESG performance affect the financial performance of environmentally sensitive industries? A comparison between emerging and developed markets. PressAcademia Procedia (PAP), 14, 135-136.

Permanent link to this document: http://doi.org/10.17261/Pressacademia.2021.1509

Copyright: Published by PressAcademia and limited licensed re-use rights only.

\section{ABSTRACT}

Purpose- The study aims to investigate whether the ESG performance of corporations from environmentally sensitive industries has any effects on their financial performance and whether the impacts of the ESG performance of environmentally sensitive corporations differ between developed and emerging countries.

Methodology- The ESG performance scores and financial performance scores for a 10-year period have been collected from the Thomson Reuters Eikon database and panel regression analyses have been carried out to evaluate the economic value of the ESG performance of these corporations.

Findings- Our findings show that the overall ESG performance of environmentally sensitive corporations has a significant positive relationship with the return on equity (ROE) and the Tobin's $Q$ of the corporations. In addition, the overall ESG performance of the environmentally sensitive corporations from developed countries has positive impact on the ROE and on the Tobin's Q whereas the ESG performance score of the environmentally sensitive corporations from emerging countries does not have any significant effect on their corporate financial performance. The findings also indicate that the impacts of the ESG performance of environmentally sensitive corporations on their financial performance are stronger in developed countries than in emerging countries.

Conclusion- This study contributes to the literature by adding a better understanding of the ESG-financial performance relationship of
\end{abstract} environmentally sensitive corporations from both developed and emerging market contexts.

Keywords: ESG performance, environmentally sensitive industry, corporate social responsibility, financial performance. JEL Codes: M14, G34

This article is produced from the Master Thesis of the Graduate student Nasruzzaman Naeem who studies in the Graduate school of Finance, the program of International Finance.

\section{REFERENCES}

Alshehhi, A., Nobanee, H., \& Khare, N. (2018). The impact of sustainability practices on corporate financial performance: literature trends and future research potential. Sustainability, 10(2), 494. https://doi.org/10.3390/su10020494

Atan, R., Alam, Md. M., Said, J., \& Zamri, M. (2019). the impacts of environmental, social, and governance factors on firm performance: panel study of Malaysian companies [Preprint]. SocArXiv. https://doi.org/10.31235/osf.io/ntz52

Bhaskaran, R. K., Ting, I. W. K., Sukumaran, S. K., \& Sumod, S. D. (2020). Environmental, social and governance initiatives and wealth creation for firms: An empirical examination. Managerial and Decision Economics, 41(5), 710-729. https://doi.org/10.1002/mde.3131

Cek, K., \& Eyupoglu, S. (2020). Does environmental, social and governance performance influence economic performance? Journal of Business Economics and Management, 21(4), 1165-1184. https://doi.org/10.3846/jbem.2020.12725

Chelawat, H., \& Trivedi, I. V. (2016). The business value of ESG performance: The Indian context. Asian Journal of Business Ethics, 5(1-2), 195-210. https://doi.org/10.1007/s13520-016-0064-4 
De Lucia, C., Pazienza, P., \& Bartlett, M. (2020). Does good ESG lead to better financial performances by firms? Machine learning and logistic regression models of public enterprises in Europe. Sustainability, 12(13), 5317. https://doi.org/10.3390/su12135317

Driscoll, J. C., \& Kraay, A. C. (1998). Consistent covariance matrix estimation with spatially dependent panel data. Review of Economics and Statistics, 80(4), 549-560.

Friede, G., Busch, T., \& Bassen, A. (2015). ESG and financial performance: Aggregated evidence from more than 2000 empirical studies. Journal of Sustainable Finance \& Investment, 5(4), 210-233. https://doi.org/10.1080/20430795.2015.1118917

Friedman, M. (1970). A Friedman doctrine: The social responsibility of business is to increase its profits. The New York Times Magazine, 13(1970), 32-33.

Friedmann, M. (1962). Capitalism and freedom. Chicago/London, 111977.

Galbreath, J. (2013). ESG in focus: The Australian evidence. Journal of Business Ethics, 118(3), 529-541. https://doi.org/10.1007/s10551-0121607-9

Garcia, A. S., Mendes-Da-Silva, W., \& Orsato, R. J. (2017). Sensitive industries produce better ESG performance: Evidence from emerging markets. Journal of Cleaner Production, 150, 135-147. https://doi.org/10.1016/j.jclepro.2017.02.180

Hoechle, D. (2007). Robust standard errors for panel regressions with cross-sectional dependence. The Stata Journal: Promoting Communications on Statistics and Stata, 7(3), 281-312. https://doi.org/10.1177/1536867X0700700301

Landi, G., \& Sciarelli, M. (2019). Towards a more ethical market: The impact of ESG rating on corporate financial performance. Social Responsibility Journal, 15(1), 11-27. https://doi.org/10.1108/SRJ-11-2017-0254

Laskar, N., Chakraborty, T. K., \& Maji, S. G. (2017). Corporate sustainability performance and financial performance: empirical evidence from Japan and India. Management and Labour Studies, 42(2), 88-106. https://doi.org/10.1177/0258042X17707659

Manrique, S., \& Martí-Ballester, C.-P. (2017). Analyzing the effect of corporate environmental performance on corporate financial performance in developed and developing countries. Sustainability, 9(11), 1957. https://doi.org/10.3390/su9111957

María Miralles-Quirós, José Miralles-Quirós, \& Luis Valente Gonçalves. (2018). The value relevance of environmental, social, and governance performance: The Brazilian case. Sustainability, 10(3), 574. https://doi.org/10.3390/su10030574

Ng, T.-H., Lye, C.-T., Chan, K.-H., Lim, Y.-Z., \& Lim, Y.-S. (2020). Sustainability in Asia: The Roles of financial development in environmental, social and governance (ESG) performance. Social Indicators Research, 150(1), 17-44. https://doi.org/10.1007/s11205-020-02288-w

Orlitzky, M., Schmidt, F. L., \& Rynes, S. L. (2003). Corporate social and financial performance: A meta-analysis. Organization Studies, 24(3), 403-441.

Pätäri, S., Jantunen, A., Kyläheiko, K., \& Sandström, J. (2012). Does sustainable development foster value creation? Empirical evidence from the global energy industry: Does sustainable development foster energy firms' value creation? Corporate Social Responsibility and Environmental Management, 19(6), 317-326. https://doi.org/10.1002/csr.280

Peiro, S. A., Segarra, O. M., Mondejar, J. J., \& Vargas, V. M. (2013). Influence of the environmental, social and corporate governance ratings on the economic performance of companies: An overview.

Studenmund, A. H. (2014). Using econometrics a practical guide. Pearson.

Tarmuji, I., Maelah, R., \& Tarmuji, N. H. (2016). The impact of environmental, social and governance practices (ESG) on economic performance: Evidence from ESG score. International Journal of Trade, Economics and Finance, 7(3), 67-77.

Ting, I. W. K., Azizan, N. A., Bhaskaran, R. K., \& Sukumaran, S. K. (2019). corporate social performance and firm performance: comparative study among developed and emerging market firms. Sustainability, 12(1), 26. https://doi.org/10.3390/su12010026

Velte, P. (2017). Does ESG performance have an impact on financial performance? Evidence from Germany. Journal of Global Responsibility, 8(2), 169-178. https://doi.org/10.1108/JGR-11-2016-0029

Yoon, B., Lee, J., \& Byun, R. (2018). Does ESG performance enhance firm value? Evidence from Korea. Sustainability, 10(10), $3635-3642$. https://doi.org/10.3390/su10103635

Yu, M., \& Zhao, R. (2015). Sustainability and firm valuation: An international investigation. International Journal of Accounting \& Information Management, 23(3), 289-307. https://doi.org/10.1108/IJAIM-07-2014-0050

Zhao, C., Guo, Y., Yuan, J., Wu, M., Li, D., Zhou, Y., \& Kang, J. (2018). ESG and corporate financial performance: Empirical evidence from China's listed power generation companies. Sustainability, 10(8), 2607-2616. 